\title{
Vitamin K: content in food consumed in São Paulo, Brazil
}

\author{
Simone Aparecida dos Santos Conceição Faria*, Vanilda Aparecida Soares de Arruda, Elias da Silva \\ Araújo, Marilene De Vuono Camargo Penteado
}

\author{
Department of Food and Experimental Nutrition, Faculty of Pharmaceutical Sciences, University of São Paulo
}

\begin{abstract}
Recent research on Vitamin $\mathrm{K}$ has shown its importance in maintaining vascular and bone health. Brazilian food composition tables do not show phylloquinone content in national foods. These data are needed to obtain more reliable results in nutritional status assessment studies of individuals in relation to this vitamin as studies have shown a geographical influence in food phylloquinone content. This study aims to determine phylloquinone (Vitamin $\mathrm{K}_{1}$ ) levels in its most important source: dark green leaved vegetables. Several varieties of vegetables were purchased directly from CEAGESP (General Warehouse Company of São Paulo) at different times. Phylloquinone was extracted using organic solvents and quantified by High Performance Liquid Chromatography - HPLC. Results show the concentrations of phylloquinone in commonly consumed foodstuffs. In general, results showed variations with data from literature on the amount of Vitamin $\mathrm{K}$ in the plants analysed.
\end{abstract}

Keywords: Phylloquinone/determination/leaf vegetables. Food composition. High Performance Liquid Chromatography. Vitamin K/study/Brazil. Cooking/Loss.

\section{INTRODUCTION}

Vitamin $\mathrm{K}$ is a fat-soluble vitamin that was originally identified as an essential factor in blood synthesis of coagulation proteins (factors II, VII, IX, and X) (Booth, Davidson, Sadowski, 1994). Several recent studies have demonstrated an important role in maintaining vascular and bone health through the Vitamin K-dependent proteins (Claussen et al., 2015; Viegas et al., 2014; Yamaguchi, 2014; Beulens et al., 2013; Booth, 2012). The natural forms of Vitamin $\mathrm{K}$ are: phylloquinone and menaquinone, the latter being synthesized by bacteria in the intestinal flora and known as "menaquinone-n" or Vitamin $\mathrm{K}_{2}$ (Booth, 2012; Penteado, 2003). Vitamin $\mathrm{K}_{1}$ (phylloquinone) is found in foods of both animal and vegetable origin, but is the only analogue of the vitamin present in plants, being predominantly found in vegetables and vegetable oils (Booth, 2012; Damon et al., 2005). Although it is generally assumed that Vitamin K deficiency is probably more common than previously believed, there are several questions about recommended adequate intake (AI) levels and the true dietary requirement of

*Correspondence: S.A.S.C. Faria. Departamento de alimentos de nutrição Experimental. Faculdade de Ciências Farmacêuticas. Universidade de São Paulo. Av. Prof. Lineu Prestes, 580, Bl. 14 - 05508-900 - São Paulo, SP - Brasil. E-mail: sinett@usp.br
Vitamin K is unknown (Booth, 2012; Booth et al., 2003). The precise physiological functions of newly discovered Vitamin $\mathrm{K}$ proteins are not known except for the function of osteocalcin in bone growth regulation (Vermeer et al., 1996). It is also unclear which markers are best for evaluating Vitamin K status (Booth et al., 2003). With the discovery of new roles for different forms of Vitamin $\mathrm{K}$, it is important to quantify their content in a variety of foods (Elder et al., 2006). In place of biological and chemical methods, the introduction of High Performance Liquid Chromatography (HPLC) has facilitated routine analysis of Vitamin K in foods (Otles, Cagindi, 2007; Pérez-Ruiz et al., 2007; Jakob, Elmadfa, 2000; 1996; Ferland, Sadawski, 1992). Recently, methods have been developed for determining Vitamin K levels in foods using High Performance Liquid Chromatography-Tandem Mass Spectrometry HPLC-MS/MS (Claussen et al., 2015) and Gas Chromatography-Mass Spectrometry GC-MS (Jang, Moon, Shibamoto, 2015). Although, these methods offer high sensitivity and accuracy, they are very expensive for routine assays. However, separation and detection by HPLC with electrochemical and fluorescence detectors after post-column reduction is relatively convenient and stable, and provides enough sensitivity and selectivity for analysing phylloquinone in plant products (Pérez-Ruiz et al., 2007; Jakob, Elmadfa, 2000). Brazil still has no tables 
of phylloquinone levels for nationally produced foods (Dôres, Paiva, Campana, 2001). There is therefore a need to analyse Vitamin K levels in foods grown in Brazilian soil to assist researchers in the nutrition area, as studies have shown that geography can influence phylloquinone levels in analysed foods (Otles, Cagindi, 2007; Ferland, Sadawski, 1992). This study therefore aims to determine phylloquinone levels in its most important source: leafy green vegetables by HPLC fluorescence using postcolumn chemical reduction for Vitamin K derivatives.

\section{MATERIAL AND METHODS}

\section{Samples}

Samples were acquired directly from CEAGESP (São Paulo General Warehouse Company), the largest supply centre in Latin America (Brasil, 2010). Twenty different leafy vegetables were collected between February 2011 and October 2012 and a "pool" of samples was set up with approximately $10 \mathrm{~kg}$ per collection for each vegetable type (Faria, 2013). The samples were analysed at the Food Analysis Laboratory of the Department of Food and Experimental Nutrition, Pharmaceutical Sciences Faculty, University of São Paulo. The day after collection sample pre-analysis preparation began following procedures described by Kawashima and Soares (2003). For vegetables that underwent a cooking process, the procedures were as established by UNICAMP (2011) according to vegetable characteristics: for broadleaf samples, baking time was 10 minutes and for floral samples, 20 minutes. About $300 \mathrm{~g}$ of each sample was weighed on an analytical scale. They were then placed in a 4-L stainless steel pan and 1.5 L of water added. Cooking was performed on a conventional stove, always using the same stove with a medium flame. Cooking time began when the water started boiling.

\section{Analytical reference standards}

Phylloquinone analytical standard and Vitamin $\mathrm{K}_{2}$, used as internal standards (IS), were purchased from the Sigma Chemical Co. (St. Louis, MO, USA). A stock solution containing $20 \mu \mathrm{g} / \mathrm{mL}$ total phylloquinone in hexane was prepared. A similar stock solution containing of $20 \mu \mathrm{g} / \mathrm{mL}$ total IS in hexane was prepared. All standard solutions were stored refrigerated $\left(-20^{\circ} \mathrm{C}\right)$ in amber Eppendorf tubes. Working standard solutions and subsequent dilutions for construction of the standard curve were prepared according to Gao and Ackman (1995). The concentration range was $0.052-2.08 \mu \mathrm{g} \mathrm{mL}^{-1}$ ( $\mathrm{n}=10$ points) to determine the limit of detection (LOD) and limit of quantitation (LOQ) for the method. The whole procedure was protected from light.

The reagents used to prepare mobile phases and solutions for the standard curves were HPLC grades from Merck (Merck Millipore Corp., Germany). Ultrapure water was obtained through a Milli-Q Plus Direct - Q3 system from Millipore. All standard and sample solutions were filtered through a $13 \mathrm{~mm}$ diameter 0.45 $\mu \mathrm{m}$ pore size Millipore filter unit prior to injection into the chromatographic system. The mobile phases were vacuum-filtered through $0.45 \mu \mathrm{m}$ pore size nylon Millipore filter (FHLC04700) and degassed by ultrasonic bath for the required period before injection into the chromatographic system.

\section{HPLC analyses}

The extraction and concentration of phylloquinone from food matrices used organic solvents with subsequent quantification by HPLC. Analysis was based on the methodology by Jakob and Elmadfa $(2000 ; 1996)$ with an adjustment in the extract purification stage; after 5 minutes centrifuging at $3000 \mathrm{rpm}$ and $4{ }^{\circ} \mathrm{C}$, the supernatant was collected, filtered through a membrane, and transferred to a $50 \mathrm{~mL}$ evaporation flask and evaporated at $40{ }^{\circ} \mathrm{C}$ for 15 minutes using a rotary evaporator and vacuum system. The residue was dissolved in $200 \mu \mathrm{L}$ of mobile phase and $50 \mu \mathrm{L}$ was injected. A Shimadzu HPLC included a CBM-20A system (SCL-10AVP), LC-Solution Software, a SIL-20A auto sampler, an LC-20AT isocratic pump, and an RF-10AXL fluorescence detector. The separation was in reverse phase with a LiChrospher RP-18 $5 \mu$ m endcapped LiChroCART 250-4.6 column, with a pre-column from Merck and a mobile phase consisting of dichloromethane/ methanol $(10: 90 \mathrm{v} / \mathrm{v})$ with the addition of $5 \mathrm{ml}$ of methanol solution with zinc chloride $(1.37 \mathrm{~g})$, sodium acetate $(0.41$ $\mathrm{g})$ and acetic acid $(0.30 \mathrm{~g})$ per litre of mobile phase and was pumped at a flow rate $1.00 \mathrm{~mL} \mathrm{~min}{ }^{-1}$ with isocratic elution. The post-column reduction $(20 \times 4.0 \mathrm{~mm}$ id) was filled manually with zinc dust p.a. grade from Merck with particles $<45 \mu$, kept in a furnace (Shimadzu-CTO-6A) at $40{ }^{\circ} \mathrm{C}$, with fluorescence detector excitation $243 \mathrm{~nm}$ and emission $430 \mathrm{~nm}$.

\section{Validation method}

A sequence of chromatographic optimization and validation runs were performed using a set of calibration samples assayed in triplicate and quality control samples at three levels in triplicate; these were carried out on 
seven separate occasions. Procedures were performed to validate the method for: Linearity, Limit of Detection and Quantification, Precision, Accuracy, Selectivity and Robustness (Lanças, 2004; Ribani et al., 2004; Youden, Steiner, 1975).

\section{Statistical analysis}

The experiments were conducted in a completely randomized way and all data were tested for normal distribution (Shapiro-Wilk's test) and homogeneity of variance (Levene and Brown-Forsythe's tests). For fresh vegetables analysed in nature, analyses of variance (ANOVA) were performed with a random factor followed by Bonferroni multiple comparisons (Neter, et al., 1996) to compare Vitamin K levels at two different times per sample. Vitamin K greenery from CEAGESP and American values were compared by using the Student $t$ test against a fixed value (Kirkwood, Sterne, 2006). The results were expressed as means of results \pm standard deviation. All statistical analyses were performed using the STATISTICA 8.0 program with a significance level of $5 \%(\mathrm{p}<0.05)$.

\section{RESULTS AND DISCUSSION}

Vitamin K can be separated by normal and reverse phase chromatography. In this work, the reversed-phase $\mathrm{C}_{18}$ system was used as the chromatography column showed good resolution on simultaneous separation of phylloquinone peaks. These conditions were also used by Otles and Cangindi (2007). The use of post-column reduction proved important for detection as no natural Vitamin K homologues emit fluorescence. Sample fluorescence was induced using a chemical reduction method employed by some authors to quantify Vitamin $\mathrm{K}$ in green vegetables (Pérez-Ruiz et at., 2007; Penteado, 2003; Kamao et al., 2005; Maccrehan, Schönberger, 1995). The method was stated to be specific and linear in the range of $0.025-2.8 \mu \mathrm{g} / \mathrm{mL}(\mathrm{r}=0.9997)$. Precision was demonstrated by calibration curve standard deviation $(\mathrm{SD}=0.0088)$. The method is robust relative to changes in flow rate, column, and temperature. Detection and quantitation limits were 0.0051 and $0.0157 \mu \mathrm{g} / \mathrm{mL}$ respectively.

Selected method precision was tested and the accuracy of the selected methods was tested and phylloquinone recovery calculated by adding three standard levels $(25,50$ and 100\%). Standard recovery corresponded to $80 \%$ based on sample concentration.

Leafy vegetables occupy an important place in well balanced diets with the most common leafy vegetables consumed raw in Southeast Brazil being lettuce, arugula, and watercress, with cabbage, cauliflower, endive, and spinach used as cooked vegetables (Kawashima, Soares, 2003). The lack of information on the composition of Brazilian foods highlights the need for more data on the composition of leafy vegetables as these are present in the main meals of all social classes (Kawashima, Soares, 2003; Dôres, Paiva, Campana, 2001). Brazilian researchers explain that the national bibliography is quite sparse regarding Vitamin $\mathrm{K}$; for this reason, it is necessary to carry out further studies and improve composition tables, to increase knowledge of Vitamin K levels in Brazilian foods (Klack, Carvalho, 2006; Dôres, Paiva, Campana, 2001).

Table I shows the means of triplicate data for both in nature and processed samples collected at CEAGESP at different times of the year in 2011 and 2012. Results show that higher levels of phylloquinone were found in raw leafy vegetables, which was present in those with darker green leaves and/or darker flowers, such as parsley, spinach, broccoli, kale, chicory catalogna, and watercress. These results agree with literature (Beulens et al., 2013; Booth, 2012) which mentions the group of dark green vegetables as foods rich in phylloquinone and state that this compound should be associated with tissues that perform photosynthesis, causing dark green vegetables with high chlorophyll concentrations to contain the highest levels of the vitamin. In contrast, lower levels were obtained in samples of cauliflower, lettuce, and chard; these vegetables are lighter green. Data from in nature vegetables were compared for different seasons of the year. These results generally showed statistical differences in Vitamin K levels for all samples. There was significant temporal variation in maximum and minimum Vitamin K levels except for samples of chicory catalogna $279-280 \mu \mathrm{g} / 100 \mathrm{~g}$ and chard $150-153 \mu \mathrm{g} / 100 \mathrm{~g}$. This variation factor was particularly accentuated in broccoli which presented high and low mean vitamin values of $374 \mu \mathrm{g}$ and $192 \mu \mathrm{g} / 100 \mathrm{~g}$, in broccoli raab of 369 and $165 \mu \mathrm{g} / 100 \mathrm{~g}$, and in spinach of 383 and $113 \mu \mathrm{g} / 100 \mathrm{~g}$. These results showed that for most in nature samples, the spring/summer seasons were favourable for achieving higher Vitamin K levels whereas the autum/winter periods produced the lowest concentrations phylloquinone (Faria, 2013). Booth (2012) likewise reports that the amount of phylloquinone increases more in summer than winter months. Some possible causes for the variations in phylloquinone levels of samples grown in Southeast Brazil are cultivating, planting location, agricultural practices, such as irrigation and possibly temperature. 
For the latter, drastic temperature changes during the year cause prolonged periods of drought and irregular rainfall - conditions which have also been cited by Kawashima and Soares (2003) to explain the variations in mineral content found in samples of fresh leafy vegetables such as lettuce, kale, spinach, cabbage and chicory purchased from markets in Southeast Brazil.
Regarding processed samples, the aim was to reproduce the domestic practice of heat treatment for products such as leafy and floral vegetables commonly used in Brazilian cuisine (UNICAMP, 2011). Table I shows the influence of domestic processing on total phylloquinone content for the evaluated vegetables. In most cases the cooking process produced losses in

TABLE I - Concentration of phylloquinone in fresh and processed vegetables

\begin{tabular}{|c|c|c|}
\hline Sample Identification & Mean $(\mu \mathrm{g} / 100 \mathrm{~g})$ & Range \\
\hline$\overline{\text { Arugula (Eruca sativa L.) }}$ & 289 & $228-319$ \\
\hline Basil (Ocimum basilicum L.) & 335 & $283-386$ \\
\hline Raw Broccoli (Brassica oleracea L. var. italica) & 279 & $192-374$ \\
\hline Cooked Broccoli & 267 & $131-404$ \\
\hline Raw Broccoli Raab (Brassica oleracea L. var. italica Plenck) & 260 & $165-369$ \\
\hline Cooked Broccoli Raab & 228 & $205-250$ \\
\hline Raw Cabbage (Brassica oleracea L. var. capitata) & 328 & $319-353$ \\
\hline Cooked Cabbage & 244 & $197-290$ \\
\hline Raw Chicory Catalogna (Cichorium Intybus L.) & 280 & $279-280$ \\
\hline Cooked Chicory Catalogna & 226 & $171-281$ \\
\hline Raw Cauliflower (Brassica oleracea var. botrytis L.) & 37 & $23-46$ \\
\hline Cooked Cauliflower & 56 & 47- 66 \\
\hline Raw Celery (Apium graveolens L. var. rapaceum) & 295 & $268-322$ \\
\hline Cooked Celery & 309 & $293-324$ \\
\hline Raw Swiss chard (Beta orientalis L.) & 152 & $150-153$ \\
\hline Cooked Swiss chard & 122 & $118-127$ \\
\hline Raw Endive (Cichorium endivia L.) & 176 & $172-205$ \\
\hline Cooked Endive & 209 & $175-243$ \\
\hline Chives (Allium fistulosum) & 160 & $105-192$ \\
\hline Raw Kale (Brassica oleracea var. acephala) & 280 & $212-362$ \\
\hline Cooked Kale & 269 & $221-326$ \\
\hline Coriander (Coriandrum sativum L.) & 258 & $215-300$ \\
\hline Raw Chinese Cabbage (Brassica rapa pekinensis (Lour.) Hanelt) & 153 & $118-208$ \\
\hline Cooked Chinese Cabbage & 189 & $172-243$ \\
\hline Raw Escarole (Cichorium endivia) & 174 & $110-230$ \\
\hline Cooked Escarole & 155 & $119-234$ \\
\hline Iceberg Lettuce (Lactuca sativa capitata) & 113 & $86-147$ \\
\hline Leafy Lettuce (Lactuca sativa L.) & 135 & $113-158$ \\
\hline Mint (Mentha longifolia) & 364 & $380-348$ \\
\hline Parsley (Petroselinum hortense) & 491 & $357-558$ \\
\hline Raw Spinach (Spinacea oleracea L.) & 375 & $316-423$ \\
\hline Cooked Spinach & 262 & $113-383$ \\
\hline Watercress (Nasturtium officinale) & 301 & $264-347$ \\
\hline
\end{tabular}

Analyses carried out in triplicate and results expressed as mean $\pm \mathrm{SD}=$ Standard Deviation. Samples that have undergone the cooking process followed the methodology of TACO - Brazilian Table of Food Composition - UNICAMP. 
phylloquinone content compared to the raw values with some samples such as spinach, broccoli and cabbage showing losses of up to $30 \%$ indicating consumption in the raw form would provide better utilization of the vitamin. Kale samples lost an average of $1.15 \%$ of phylloquinone, indicating practically no loss was suffered from the effects of cooking. Chicory, cauliflower and celery samples showed higher levels of the vitamin in processed samples than their raw counterparts; we can therefore conclude that the cooking process favoured higher vitamin extraction due to disrupting the cell membranes of the food matrices by heating leaving the compound of interest more exposed thus facilitating its extraction. This factor was also reported by Gliszczynska-Swiglo et al. (2006) in a study evaluating cooking by boiling vegetable samples. The differentiated behaviour observed in relation to vitamin content of samples which have experienced the cooking process may have been caused by the loss or amount of water incorporated by the samples through the process. The effects of cooking by steam and microwave on phytochemical substances (polyphenols, carotenoids and ascorbic acid) in foods such as fresh fruits and vegetables have been extensively studied with both positive and negative effects reported depending on differences in process conditions, morphology, and nutritional characteristics of different plant species (Mazzeo et al., 2011; Pellegrini et al., 2010; Miglio et al., 2008; Gliszczynska-Swiglo et al., 2006; Turkmen, Sari, Velioglu, 2005). Mazzeo et al. (2011) evaluated the effects of steaming and boiling spinach and cauliflower samples and reported that both treatments showed significant changes in the nutritional composition both vegetables. Pellegrini et al. (2010) demonstrated that different thermal household processes increased the bioavailability of polyphenols and carotenoids, highlighting the positive role of cooking on the nutritional qualities of vegetables. These improvements offered by heat treatment in vegetables were also reported by Damon et al. (2005) and Miglio et al. (2008). Pellegrini et al. (2010) reported that the absorption efficiency of phylloquinone can vary substantially and be less efficient when the food is eaten raw because the vitamin is intimately linked to the thylakoid and chloroplast membranes in the cells of these plants. Absorption is most efficient when foods are ingested processed because breaking the food matrix promotes increased bioavailability of many phytochemicals thereby improving the nutritional quality of the plants. The authors also emphasize that existing data on different methods of thermal vegetable processing are fragmented and incomplete making it difficult to make comparisons between studies.
Evaluation of phylloquinone levels in samples collected at CEAGESP compared to those of USDA. Table II presents the mean of triplicate samples collected at CEAGESP during different seasons of 2011 and 2012 compared to levels for the same vegetables in the USDA database.

TABLE II - Comparison between Brazilian and American phylloquinone concentration data in fresh vegetables $(\mu \mathrm{g} / 100 \mathrm{~g})$

\begin{tabular}{lccc}
\hline $\begin{array}{l}\text { Samples } \\
\text { in nature }\end{array}$ & $\begin{array}{c}\text { CEAGESP* } \\
\text { Mean }\end{array}$ & USDA** & $\mathrm{p}$ \\
\hline Iceberg lettuce & 113 & 24 & $<\mathbf{0 . 0 0 1}$ \\
Leaf lettuce & 135 & 126 & 0.315 \\
Parsley & 491 & 1640 & $<\mathbf{0 . 0 0 1}$ \\
Arugula & 289 & 109 & $<\mathbf{0 . 0 0 1}$ \\
Chard & 152 & 231 & $<\mathbf{0 . 0 0 1}$ \\
Cabbage & 328 & 76 & $<\mathbf{0 . 0 0 1}$ \\
Spinach & 375 & 483 & $<\mathbf{0 . 0 0 1}$ \\
Kale & 280 & 437 & $<\mathbf{0 . 0 0 1}$ \\
Cauliflower & 37 & 15 & $<\mathbf{0 . 0 0 1}$ \\
Broccoli & 279 & 102 & $<\mathbf{0 . 0 0 1}$ \\
Broccoli Raab & 260 & 225 & $<\mathbf{0 . 0 0 1}$ \\
Chives & 160 & 213 & $<\mathbf{0 . 0 0 1}$ \\
Coriander & 258 & 310 & $<\mathbf{0 . 0 0 1}$ \\
Celery & 295 & 29 & $<\mathbf{0 . 0 0 1}$ \\
chicory & 176 & 298 & $<\mathbf{0 . 0 0 1}$ \\
Watercress & 301 & 250 & $<\mathbf{0 . 0 0 1}$ \\
\hline
\end{tabular}

* Triplicate results from GEACESP samples analysed at different times of the year in 2011 and 2012. **USDA - United States Department of Agriculture. $p=$ Descriptive level of statistical test.

Table II shows that only raw leafy lettuce has statistically the same amount of phylloquinone $(p>0.05)$ as online data from the United States Department of Agriculture - USDA. Parsley, chard, spinach, kale, chives, coriander, and chicory samples sourced from CEAGESP have lower vitamin content, and iceberg lettuce, arugula, cabbage, cauliflower, broccoli, celery and watercress have higher vitamin content than online USDA data $(p<0.05)$. Table III shows data from other studies and highlights significant variations in phylloquinone content for the same vegetables. As described here and by other authors, differences in phylloquinone levels for certain vegetables according to geographic location suggest that levels of this vitamin may be influenced by growing conditions, soil, climate, and agricultural tracts (Booth, 2012; Klack, Carvalho, 2006). 
TABLE III - Comparison between different studies for phylloquinone content in vegetables $(\mu \mathrm{g} / 100 \mathrm{~g})$

\begin{tabular}{lcccccc}
\hline & $\mathbf{1}$ & $\mathbf{2}$ & $\mathbf{3}$ & $\mathbf{4}$ & $\mathbf{5}$ & This study \\
\hline Broccoli & $147-205$ & 178 & 110 & $113-180$ & 179 & 308 \\
Cauliflower & $27-39$ & - & 20 & 20 & 31 & 37 \\
Leafy lettuce & $120-140$ & $519-1180$ & 160 & 122 & 129 & 147 \\
Iceberg lettuce & - & - & 40 & 31 & - & 126 \\
Spinach & $294-433$ & $1001-1439$ & 270 & $300-380$ & 380 & 404 \\
Cabbage & $174-204$ & $449-719$ & 60 & 145 & 339 & 336 \\
Parsley & $530-560$ & - & 360 & - & 548 & 558 \\
Watercress & - & - & - & - & 315 & 320 \\
Kale & - & $621-1657$ & - & 440 & - & 313 \\
\hline
\end{tabular}

1) Bolton-Smith et al., 2000 2) Ferland, Sadowski, 1992; 3) Koivu et al., 1997; 4) Booth, 2012 and Booth et al., 1994; 5) Shearer et al., 1996

Table III compares phylloquinone content in vegetables from this study with other data from literature.

Knowledge on Vitamin $\mathrm{K}$ in food is very important in studies which evaluate the relationship between dietary vitamin intake and nutritional status of the individual. Significant variations can be seen in consumption levels for this vitamin in different studies: Booth et al. (2004) analysing Vitamin $\mathrm{K}$ intake and bone mineral density in men and women, observed a consumption of $171 \mu \mathrm{g} /$ day for women and $153 \mu \mathrm{g} /$ day for men. However, average phylloquinone consumption in The Rotterdam Study was $244 \mu \mathrm{g} /$ day for women and $257 \mu \mathrm{g} /$ day for men (Geleijnse et al., 2004). The discrepancies between Vitamin K levels in different food composition tables may reflect the results of these studies on the intake of this vitamin. Research has shown that Vitamin $\mathrm{K}$ has been inadequately studied; one of the biggest issues is related to the food composition tables presenting large variations in Vitamin $\mathrm{K}$ levels for the same food. Researchers emphasize that geographical differences in food composition data should be considered when applying database composition values for regional surveys (Booth, 2012; Souza, Rodrigues, Penteado, 2012; Klack, Carvalho, 2006; Dôres, Paiva, Campana, 2001). For this reason, further studies are needed to improve composition tables and increase knowledge on Vitamin K levels in Brazilian foods. In summary, the results of this study show variations in phylloquinone content between analysed samples and data described in international literature for the same vegetables; this can be explained by the influence of geographical differences. The validation procedure for the analysis method used in this study was effective and can be used in determining phylloquinone levels in leafy vegetable samples. The processing of leafy vegetables by cooking caused changes in phylloquinone levels compared to fresh samples. Most vegetables obtained in spring showed the highest levels of phylloquinone.

\section{ACKNOWLEDGEMENTS}

The authors would like to thank São Paulo Teaching and Research Foundation Support - CNPq (the Brazilian National Council Scientific and Technological Development) for their financial support.

\section{REFERENCES}

BEULENS, J.W.J.; BOOTH, S.L.; VAN DEN HEUVEL, E.G.H.M.; STOECKLIN, E.; BAKA, A.; VERMEER, C. The role of menaquinones (Vitamin $\mathrm{K}_{2}$ ) in human health. Brit. J. Nutr., v.110, n.8, p.1-12, 2013.

BOLTON-SMITH, C.; PRICE, R.J.G.; FENTON, S.T.; HARRINGTON, D.J.; SHEARER, M.J. Compilation of provisional UK database for the phylloquinone $\left(\right.$ Vitamin $\left._{1}\right)$ content of foods. Brit. J. Nutr., v.83, n.4, p.389-399, 2000.

BOOTH, S.L. Vitamin K: food composition and dietary intakes. J. Food Nutr., v.56, p. 5505, 2012.

BOOTH, S.L.; GOLLY, I.; SACHECK, J.M.; ROUBENOFF, R.; DALLAL, E.G.; HAMADA, K.; BLUMBERG, J.B. Effect of vitamin E supplementation on Vitamin K status in adults with normal coagulation status. Am. J. Clin. Nutr., v.80, n.1, p.143-148. 2004.

BOOTH, S.L.; MARTINI, L.; PETERSON, J.W.; SALTZMAN, E.; DALLAL, G.E.; WOOD, R.J. Dietary phylloquinone depletion and repletion in older women. J. Food Nutr., v.133, n.8, p.2565-2569, 2003. 
BOOTH, S.L.; DAVIDSON, K.W.; SADOWSKI, J.A. Evaluation of an HPLC method for the determination of phylloquinone (Vitamin $\mathrm{K}_{1}$ ) in various food matrices. $J$. Agric. Food Chem., v.42, n.2, p.295-300, 1994.

BRASIL. Ministério da Agricultura, Pecuária e Abastecimento. PROHORT - Programa Brasileiro de Modernização do Mercado Hortigranjeiro. Disponível em: <http://www. ceasa.gov.br/index.php?pag=10>. Access: May 19, 2010.

CLAUSSEN, F.A.; TAYLOR, M.L.; BREEZE, M.L.; LIU, K. Measurement of Vitamin $\mathrm{K}_{1}$ in commercial canola cultivars from growing locations in north and south America using High-Performance Liquid Chromatography-Tandem Mass Spectrometry. J. Agric. Food Chem., v.63, p.1076-1081, 2015.

DAMON, M.; ZHANG, N.Z.; HAYTOWITZ, D.B.; BOOTH, S.L. Phylloquinone (Vitamin $\mathrm{K}_{1}$ ) content of vegetables. $J$. Food Compos. Anal., v.18, n.8, p.751-758, 2005.

DÔRES, S.M.C.; PAIVA, S.A.R.; CAMPANA, A.O. Vitamina K: metabolismo e nutrição. Rev. Nutr., v.14, n.3, p.207-218, 2001 .

ELDER, S.J.; HAYTOWITZ, D.B.; HOWE, J.; PETERSON, J.W.; BOOTH, S.L. Vitamin K contents of meat, dairy, and fast food in the U.S. diet. J. Agric. Food Chem., v.54, n.2, p.463-467, 2006.

FARIA, S.A.S.C. Teores de vitamina $\mathrm{K}$ em hortaliças consumidas na cidade de São Paulo. 2013. 113f. Tese (Doutorado em Ciências dos Alimentos) - Faculdade de Ciências Farmacêuticas, Universidade de São Paulo, São Paulo, 2013.

FERLAND, G.; SADAWSKI, J.A. Vitamin $\mathrm{K}_{1}$ (phylloquinone) content of green vegetables: Effects of plant Maturation and geographical growth location. J. Agric. Food Chem., v.40, n.10, p.1874-1877, 1992.

GAO, Z.H.; ACKMAN, R.G. Determination of vitamin $\mathrm{K}_{1}$ in canola oils by high performance liquid chromatography with menaquinone-4 as an internal standard. Food Res. Int., v.28, n.1, p.61-69, 1995.

GELEIJNSE, J.M.; VERMEER, C.; GROBBEE, D.E; SCHURGERS, L.J.; KNAPEN, M.H.; VAN DER MEER, I.M.; HOFMAN, A.; WITTEMAN, J.C. Dietary intake of menaquinone is associated with a reduced risk of coronary heart disease: the Rotterdam Study. J. Nutr., v.134, n.11, p.3100-3105, 2004.
GLISZCZYNSKA-SWIGLO, A.; CISKA, E.; PAULAKLEMANSKA, K.; CHMIELEWSKW, J.; BORKOWSKW, T.; TYRAKOWSKA, B. Changes in the content of healthpromoting compounds and antioxidant activity of broccoli after domestic processing. Food Addit. Contam., v.23, n.11, p.1088-1098, 2006.

JAKOB, E.; ELMADFA, I. Rapid and simple HPLC analysis of Vitamin $\mathrm{K}$ in food, tissues and blood. Food Chem., v.68, n.2, p.219-221, 2000.

JAKOB, E.; ELMADFA, I. Application of a simplified HPLC assay for the determination of phylloquinoone (Vitamin $\mathrm{K}_{1}$ ) in animal and plant food items. Food Chem., v.56, n.1, p.87-91, 1996.

JANG, H.S.; MOON, J-K.; SHIBAMOTO, T. Analysis and antioxidant activity of extracts from broccoli (Brassica oleracea L.) Sprouts. J. Agric. Food Chem., v.63, n.4, p.1169-1174, 2015.

KAWASHIMA, L.M.; SOARES, L.M.V. Mineral profile of raw and cooked leafy vegetables consumed in southern Brazil. J. Food Compos. Anal., v.16, n.5, p.605-611, 2003.

KAMAO, M.; SUHARA, Y.; TSUGAWA, N.; OKANO, T. Determination of plasma Vitamin $\mathrm{K}$ by high-performance liquid chromatography with fluorescence detection using Vitamin K analogs as internal standards. J. Chromatogr. B., v.816, n.1-2, p.41-48, 2005.

KIRKWOOD, B.R.; STERNE, J.A.C. Essential medical statistics. 2.ed. Malden: Blackwell Science, 2006.

KLACK, K.; CARVALHO, J.F. Vitamina K: metalobismo, fontes e interação com o anticoagurante varfarina. Rev. Bras. Reumatol., v.46, n.6, p.398-406, 2006.

KOIVU, T.J.; PIIRONEN, V.I.; HENTTONEN, S.K.; MATTILA, P.H. Determination of phylloquinone in vegetables, fruits, and berries by High-Performance Liquid Chromatography with eletrochemical detection. J. Agric. Food Chem., v. 45, n.12, p.4644-4649, 1997.

LANÇAS, F.M. Validação de métodos cromatográficos de análise. 6. ed. São Carlos: Rima, 2004. v.1, 62p.

MACCREHAN, W.A.; SCHÖNBERGER, E. Determination of Vitamin $\mathrm{K}_{1}$ in serum using catalytic-reduction liquid chromatography with fluorescence detection. J. Chromatogr. B., v.670, n.2, p.209-217, 1995. 
MAZZEO, T.; N'DRI, D.; CHIVARO, E.; VISCONTI, A.; FOGLIANO, V.; PELLEGRINI, N. Effect of two cooking procedures on phytochemical compounds, total antioxidant capacity and colour of selected frozen vegetables. Food Chem., v.128, n.3, p.627-233, 2011.

MIGLIO, C.; CHIAVARO, E.; VISCONTI, A.; FOGLIANO, V.; PELLEGRINI, N. Effects of different cooking methods on nutritional and physicochemical characteristics of selected vegetables. J. Agric. Food Chem. v.56, n.1, p.139-147, 2008 .

NETER, J.; KUTNER, M.H.; NACHTSHEIM, C.J.; WASSERMAN, W. Applied linear statistical models. Boston: WCB, McGraw-Hill, 1996. 1408p. (Irwin Series in Statistics).

OTLES, S.; CAGINDI, O. Determination of vitman $\mathrm{K}_{1}$ content in olive oil, chard and human plasma by RP-HPLC method with UV-Vis detection. Food Chem., v.100, n.3, p.1220$1222,2007$.

PELLEGRINI, N.; CHIAVARO, E.; GARDANA, C.; MAZZEO, T.; CONTINO, D.; GALLO, M.; RISO, P.; FOGLIANO, V.; PORRINI, M. Effect of different cooking methods on color, phytochemical concentration, and antioxidant capacity of raw and frozen brassica vegetables. J. Agric. Food Chem., v.58, n.7, p.4310-4312, 2010.

PENTEADO, M.D.V.C. Vitaminas: aspectos nutricionais, bioquímicos, clínicos a analíticos. Barueri: Manole, 2003. v. 1,612 p.

PÉREZ-RUIZ, T.; MARTÍNEZ-LOZANO, C.; GARCÍA, M.D.; MATÍN, J. High-performance liquid chromatographyphotochemical reduction in aerobic conditions for determination of $\mathrm{K}$ vitamins using fluorescence detection. J. Chromatogr. A., v.1141, n.1, p.67-72, 2007.

RIBANI, M.; BOTTOLI, C.B.G.; COLlinS, C.H.; JARDIM, I.C.S.F.; MELO, L.F.C. Validação de métodos cromatográficos e eletroforéticos. Quim. Nova, v.27, n.5, p.771-780, 2004.
SHEARER, M.J.; BACH, A.; KOHLMEIER, M. Chemistry, nutritional sources, tissue distribution and metobolism of Vitamin K with special reference to bone health. J. Nutr., v.126, n.4, p.1181S-1186S, 1996.

SOUZA, W.N.; RODRIGUES, M.L.; PENTEADO, M.D.V.C. Ingestão habitual de vitamina $\mathrm{K}$ em adultos e idosos. Rev. Nutr., v.25, n.4, p.507-515, 2012.

TURKMEN, N.; SARI, F.; VELIOGLU, Y.S. The effect of cooking methods on total phenolics and antioxidant activity of selected green vegetables. Food Chem. v.93, n.4, p.713$718,2005$.

UNIVERSIDADE ESTADUAL DE CAMPINAS. UNICAMP. TACO - Tabela de composição de alimentos. Núcleo de Estudos e Pesquisas em Alimentação. Campinas: NEPA, 2011. Disponível em: <https:/www.unicamp.br/nepa/taco/ contar/taco_4_edicao_ampliada_e_revisada $>$. Acesso em: 05 Fev. 2011.

VERMEER, C.; GLJSBERS, B.L.MLG.; CRACIUN, A.M.; DOOREN, M.M.C.L.G.; KNAPEN, M.H.J. Effects of Vitamin K on bone mass and bone metabolism. J. Nutr., v.126, Suppl. 4, p.1187S-1191S, 1996.

VIEGAS, C.S.B., HERFS, M.; RAFAEL, M.S.; ENRIQUEZ, J.L.; TEIXEIRA, A.; LUÍS, I.M.; HOOFD, C.M.R.; JOÃO, A.; MARIA, V.L.; CAVACO, S.; FERREIRA, A.; SERRA. M., THEUWISSEN, E.; VERMEER, C.; SIMES, D.C. Glarich protein is a potential new Vitamin $\mathrm{K}$ target in cancer: Evidences for a direct GRP-mineral interaction. Biomed Res. Int., v.14, ID340216, 14p., 2014.

YAMAGUCHI, M. Osteoporosis treatment with functional food factor: Vitamain $\mathrm{K}_{2}$ J. Osteopor. Phys. Act., v.2, n.1, p.1-3, 2014.

YOUDEN, W. J.; STEINER, E. H. Statistical manual of Association of Official Analytical Chemists: official metods of analysis of AOAC. Washington: AOAC, 1975. v.1, p.88.

Received for publication on $06^{\text {th }}$ October 2015 Accepted for publication on $19^{\text {th }}$ December 2016 